\title{
REVIEWING THE ANTHROPOLOGICAL STUDY OF THARUS IN NEPAL
}

\author{
Megh Prasad Kharel ${ }^{1}$
}

\begin{abstract}
This paper aims to review the varieties of Tharu anthropological writings in Nepal. It is clear that the basic notion of reviewing any area study is to pave the way for further studies as it reveals the departure and gap from previous study. At this backdrop, the review on anthropological study of Tharu in Nepali socio-cultural context discusses how the writings dealing with the Tharus community seem helpful for opening the way to further studies in this area of ethnicity with multidisciplinary approaches, such as, cultural studies, linguistics, literature, demography, history, folklore, sociology, arts and crafts and ethnography. At the same time, it also enhances to comprehend varied subgroups of Tharus in Nepal, for instances, Dangaura, Rana, Kochila, Chitwaniya and Desaura. Moreover, the present research on Tharus is comparatively more focused on anthropological study rather than other disciplines, such as, folklore, ethno-music and literature, sociology, cultural studies, linguistics, ethno-history and demography. Regarding the Tharu anthropological research, this study is an attempt to portray the huge possibility of further ethnic studies, particularly on many subgroups of Tharus in Nepali territory.
\end{abstract}

Keywords: Review, Anthropology, Study, Tharus, Departure and Multidiscipline

\section{INTRODUCTION AND OBJECTIVE}

Tharus, in general, indicate one of the largest ethnic communities of Nepal. They chiefly reside in twenty two districts of Tarai and inner Tarai region. According to Population and Housing Census 2011, the total Tharu population in Nepal is 17, 37, 470 (CBS 2012, 148). Even though the term 'Tharu' is understood as a single community in Nepal, but it shows

1 Mr. Kharel is a PhD scholar, Faculty of Humanities and Social Sciences, TU.. 
the several subgroups based cultural and linguistic diversity within Tharu community. Moreover, they are also known by regional basis as Dangaura in the mid-western, Rana in the far-western, Kochila in the eastern, Chitwaniya and Desaura in the middle region of the Tarai.

The comparative study with other ethnic groups' study is still unexplored domain. It is clear that the basic objective of reviewing any area of study is to pave the way for further studies as it reveals the departure and gap from the previous study. Regarding the varieties of Tharu anthropological writings, this study aims to explore the thematic and descriptive approaches of the previous studies on Tharus that may pave the way to underline for the further studies of Tharus in the light of multidisciplines, such as, cultural studies, linguistics, literature, demography, history, ethnography, ethnomusics, arts and crafts, folklore, sociology and history.

\section{RESEARCH METHOD}

This research paper is primarily based on library research and, therefore, the analysis of the entire article is relied on secondary sources, such as, journal articles, $\mathrm{MA}$ and $\mathrm{PhD}$ dissertations, books etc. In this review, I have followed fundamentally a thematic approach as well as descriptive approach on the different sort of Tharu writings. Using analytical and evaluative methods, this paper also enhances to comprehend the different viewpoints on the ethnicity, cultural anthropology, modernization, social and family organization as well as ritual and social practices of Dangaura Tharus.

\section{ANALYSIS OF THARU ANTHROPOLOGICAL STUDY}

Anthropology, the science of humankind, has become one of the most motivating disciplines in the academic arena in the contemporary global context. The study of anthropology is not only part of a natural and social science, but also as a subject under the humanities in the context of present interdisciplinary discourse. Within a social system, humankind becomes more a social creature than biological organism. (Roy 2003) underlines that the arrival of Darwinian theory of sociological evolution provoked to comprehend the "natural history of cultural development" in the nineteenth century that involved the culture of proliferate people in the 
worldwide (3). The biological aspect of man dealt basically under physical anthropology whereas cultural anthropology involved entire psychological, rational, social and material processes. In other words, cultural anthropology is also a product of the human being in an integrated pattern. Moreover, archaeological anthropology, linguistic anthropology and social cultural anthropology are subfield of the cultural anthropology. However, cultural anthropology deals with the social behavior of man and, accordingly, it highlights the development of customs and social behavior from prehistoric time to present way of living life.

The term 'ethnology' is popular for cultural anthropology. The Greek word 'ethnos' refers to the race or indigenous people and 'logia' means study. Thus, ethnology is the study of indigenous and racial people's living and their culture. As a significant component of cultural anthropology, ethnology has become prime concerned of "customary ways of thought and behavior of ethnic groups" that attempts to investigate the dynamics of cultural aspects in the ethnic community (7). Thus, (Haviland 1999) discusses in the relevant of cultural anthropology, which is basically hinged upon the "culture bound" theory of human behavior (11). At this backdrop, many national and foreign researchers have tried to seek the social relations and patterns of life among different subgroups of Tharus through their established institutions, such as, kinship, marriage, family, economic relations, religious practice, social and political status.

French anthropologist (Krauskopff 1995) has presented a bibliography on the anthropology of the overall Tharus, including both Nepali and Indian context. Moreover, her presentation of such bibliography reveals the outline of different anthropological researches on Dangaura, Chitwaniya, Kochila and Rana Tharus before 1995s. It seems that the process of constant migrating of Tharu groups caused difficulty to show their primitive ethnic boundary as their ancient cultural practices are in crisis. Nevertheless we have a relatively clear picture of different subgroups within Tharus of Nepal. So 'Dangauras' are such groups who have their original home in Dang valley, which is in the inner Tarai region of Nepal. At the same time, 'Ranas' are of far-western Tarai region and they claim of their Rajput origin from India. Kathariya and Desaura Tharus have been 
residing in western Tarai. It has become a common to intermarry within Tharu subgroups with the rapid process of migration and new settlement. We see the eastern Tharus are mostly Kochilas that are scattered in different districts, including Jhapa to Rautahat. Indeed, Tharus from far-western to eastern Tarai have different dialects and cultural variations. Moreover, the building of a new Tharu identity in the broader sense shows the variations from one group to another, particularly on "social organization, rituals and religious practices, village and domestic organization, mythology and festivals" (191-2). At the same time, Krauskopff also highlights the minority of Tharus in Indian context as they live in the border side, particularly in Nainital and Kheri Tarai districts of India. Moreover, they are also scattered in the south of Nepal border in Uttar Pradesh and Bihar.

The anthropological study of Dangaura Tharu was first started by Rajaure (1977), chiefly focusing on the Dang-Deukhuri valley. His master degree dissertation entitled, An Anthropological Study of the Tharu of Dang-Deokhuri, has attempted to include the descriptive inquiry of Tharu organization of Dangaura Tharu. He has used the data chiefly on the structure of Tharu gurwā (priest), community rituals and festivals from a village of Sukhrwar in Dang. It tries to examine a classical village monograph that includes the village organization, groups and clans, family life, agricultural economy, land distribution and ownership, religion and ritual objects, deities and spirits, curing and witchcraft, rites de passage, child birth, marriage, festivals and rituals, social change and interaction and the like. Indeed, the anthropological study of Rajaure reveals that social organization of Dangaura Tharus is basically the concerned of their typical based myth and ritual. Furthermore, major purpose of his study is to present a socio-economic and cultural life of Dangaura Tharus, and, accordingly, his dissertation has the limitation of ancestral based customs, religion and festivals as well as agricultural dominated economic activities.

Likewise, Rajaure (1982) encompasses the discussion of Tharu religion, which is a complex system of beliefs and practices in their way of life. Further, he asserts that traditions of Tharu local religion have been more or less attached and influenced by the tradition of Hinduism because "stories from Ramāyana and Mahäbhärata have become the themes of 
some of their songs"(94). Emphasizing the Hindu influence on their songs, Rajaure examines the distinctive based religious ways of folk Tharu life that reinforce to advance their social status by the mimicry of Hindu manners and cultures. Besides Tharus have also their own way of legend and myth as well as ancestral deities and spirits. Accordingly, they believe that almighty God had given birth to Gurubābā, who is "the first Tharu god on earth" (62). In this way, their religious and ritual conviction reveals that Tharus are the descendants of Gurubābā.

The PhD dissertation of Christian McDonaugh entitled The Tharu of Dang: A Study of Social Organization, Myth and Ritual in West Nepal (1984) mostly portrays "a descriptive analysis of the social organization, myth and ritual" of Dangaura Tharu in Dang valley (1). The opening point of his study is primarily focused on social organization, but the some following topics of myth and ritual have become essential to elaborate the collective construction as well as social units: Tharu village, the house, gotyār, kinship, marriage, deities and patrilineal group. Relying on Rajaure MA thesis, McDonaugh seeks to examine how Tharus social organization is profoundly depended upon various sorts of rituals and myths. With the portrayal of rituals and mythology, he finds that social organizations of Tharus have the particular kinship associations in their terrain. The discussion of ritual, myth, cosmology, deities of the house, gotyār and village depicts their overall ethnic identity. But these components are inseparable facets of their village organization and household organization. It is apparent that Tharu village is "a territorial unit exhibiting cohesiveness" and, accordingly, "its organization centres on the headman and village meeting of household heads" (374).

In the same way, McDonaugh (1989) highlights that Dangaura mythology "constitutes part of the underlying framework for their traditional outlook" on the one hand. On the other, their ethnic mythology has played a substantial role in the "recent moves to shape a more in self-conscious sense of Tharu culture and identity" (192). In other words, myth and folk songs represent "valued cultural resources both in terms of entertainment and aesthetic pleasure and in relation to ritual and religious knowledge" (202). Moreover, the descriptive ethnography of myths and folk songs 
are essential task of the locality, cultural features and ethnic identity. At the same time, McDonaugh (1999) tries to examine the different trends of social and economic change in the community of Tharu village in Dang, particularly the village of Sukhrwar, which lies in the central part of Dang valley. At this backdrop, McDonaugh underscores two aspects of changes and developments within the community of Dangaura Tharu. Firstly, Tharus had the condition of "isolation and greater engagement with the world around them" (232). So they had formed "a separate" and "some extent a closed community" as they preferred to live in isolation from community based people. Despite their neighboring group of Pahāri, their living was isolated. Secondly, the development of their relationship, bond and association with Pahäri has the "signs of weakening in aspects of the community organization". It shows that their communal labor has the situation of disappearing in the present social and cultural change. His ethnography study of Sukhrwar village illustrates that their tradition based social organization has more or less marked the erosion in ethnic identity.

Similarly, the study of Krauskopff (1995) also underlines the Dangaura Tharus and their social organization. It is an essential matter that ritual as a "necessary tool to understand the Dangaura Tharus' social organization" (205). Her PhD dissertation, Maitres et possedes: les diux, less rites et l'ordre social chez les Tharu (Nepal) (Masters and Possessed: Rituals and Social Order Among the Tharu) was written in French language and published in 1989. Her ethnological approach was put emphasis particularly on the monograph of Baibang and Hekuli villages of western Dang. So she spent with the company of Tharu gurwa (priest), who can treat illness and disorder of social life in the villages of Tharus. Indeed, the social and religious orders are bounded by gurwa system in their community. Besides Krauskopff (2017) explores the social and religious order as their territory and social organization is too locally rooted along with agrarian and political history.

The journal article of Krauskopff (1987), “Naissance D’un Village Tharu: A Props des rites de claustration Villageoise (The Birth of a Tharu Village: Concerning Rituals of Village Claustration)", also presents an indepth study of Tharu representations of village through two rituals: "village- 
shrine foundation" and "village-cloistering rituals"(131). Her many research articles are written in French languages, but abstract of those articles are in English as well. My paraphrasing and summarizing of her explorations and ideas are based on English version of those abstracts. For Krauskopff, ritual is a considerable identification of the Tharu representation. Similarly, in her French language piece of writing, "Les Tharu et le royaume hindou de Dang (Nepal) (The Tharu and the Hindu of Dang (Nepal)", she seeks to examine the matter of how Dangaura Tharu "endogamy is grounded" in the pattern of Hindu Kingdom in their locality (53). This study, in fact, reveals that Tharu descendant has "divine heritage linking groups to the tutelary gods of local chieftainship and indirectly to Ratannath" (53). Further, Krauskopff highlights that Tharus are native people of Tarai, who have a hereditary ritual attributions that are linked to fix shrines while a non-hereditary one has divinities without shrines.

The $\mathrm{PhD}$ dissertation of Guneratne (1998) entitled Tharu of Chitwan, Ethnicity, Class and the State in Nepal is an in-depth "study of the development of Tharu ethnic identity" as it incorporates the ethnographic study of Chitwaniya Tharus. Furthermore, it also examines changes in economy, society and culture of Tharus in Chitwan due to the extensive migrated populace from the hilly region for the last four decades. At the same time, Guneratne (2003) asserts on the role of Tharu elite that reshapes the Tharu ethnic consciousness as immigrants of the dominant hill BrahminChhetri castes have migrated in the Tarai. Consequently, it has become a big challenge to shape the traditional and structural based ethnicity. In this regard, Tharu rituals and cultural practices, which are bolstered up by Tharu elites, have become a substantial for the process of ethnic identity formation. In other words, different Tharu organizations, for instance Tharu Kalyānkāri Sabhā and Backward Society Education (BASE), have played the foremost accountability in shaping of Tharu identity because "their awareness of themselves as a distinct group with certain common interests" for the "common identity" throughout the Tarai region (193). In this way, the Tharus of lowland Nepal have the credentials of being culturally and linguistically diverse people as they shared cultural symbols, including 


\section{REVIEWING THE ANTHROPOLOGICAL STUDY OF THARUS IN NEPAL}

religion, language and common legends of their forefathers for the survival of collective and shared feeling of Tharuness.

Guneratne (1998) contends that the construction of a Tharu identity in Nepal is concerned with the ethnic consciousness. The modernization process includes "the expansion of the technologies and possibilities of communication" and, moreover, it enhances the ethnic identity in the new circumstances (769). At this backdrop, he avows that pre-modern mindset of Nepal was not an adequate and a sufficient foundation for the ethnic intensification because Prithvi Narayan Shah "set out to conquer his neighbors in the mid-eighteenth century" and he "ruled over a society consisting of different linguistic and cultural groups". In this sense, Tharu ethnic discourse of mythology and folklore has the implication of socioeconomic condition as it not only promotes class relationship, but also cultural and linguistic sides to identify the social and cultural expression in the diversity of Nepali society.

Guneratne (1969) deals with the issue of modernization and Sanskritization of Tharu children in Chitwan. His field-visit study of Chitwan area reveals that ritual of Saraswati puja is popular among Tharu children that "appears to be an act of Sanskritization, the adoption by the Tharus of a practice closely associated with high caste" (172). Indeed, Saraswati is a goddess of knowledge and learning. Accordingly, Guneratne evaluates that Saraswati is traditionally a deity of Brahmin and Chhetri caste rather a deity of Tharu people. But in the process of modernization and Sanskritization, their Children are adapting the ritualization of Saraswati goddess. Moreover, Tharus are known as alcohol-drinkers (matawalis) and their perception of high caste based rituals "involves the imitation or adoption of high caste rituals and practices" (162). On the one hand, such transformation bolsters the social mobility that is hinged upon in the political and economic status. On the other, such adaptation shows that Brahmin-Chhetri rituals have the "normative Nepalese culture" in the circumstance of Nepali society (172). Guneratne (2011) discusses that the domination of high castes in Nepali society since pre-modern has particularly in the areas of the economic, political and cultural activities. Consequently, his remark underscores the 
modernizing process of Tharu matawali caste in the lowland of Nepal by showing the close relation with the rituals of dominant caste group.

In the same way, a renowned Nepali anthropologist, Bista (2008), opines that ethnic minority members have the "prone to experiencing special forms of acculturation" as their children go to school for being an educated that "tend to adopt high caste attitudes" (57). Similarly, Bista (2013) identifies the credentials of the Nepali Tharus as he scrutinizes that Tharus are by tradition peasants and "most of the Tharus in Dang-Deokhuri have been very greatly exploited by ruthless zamindārs, landlords and revenue agents" because "they are virtually slaves in the hands of the zamindārs" (142). Elaborating the diverse historical, sociological and cultural features of Tharus, Bista further argues, "Tharus practice their tribal religion which consists of worshipping a number of spirits and some Hindu deities which have been incorporated" (146). In spite of the close contact with high-caste Hindus and Brahman priests, Tharu still practice their traditional "religion of their own gurwa $\bar{a}$. In other words, his study on Tharu is more concerned on too general survey of anthropological and sociological sides of many subgroups of Tharus rather than particular Tharu community.

Srivastava (1969) explores the lots of changes in the social organization of Tharus of Nainital Tarai of Uttar Pradesh in India during the period of 1948 s to 50 s. In other words, Tharus in India have been adopting the neighboring cultural attitudes of so-called higher cultures and civilization (11). Moreover, the cultural dynamics among the Tharus were motivated by the high caste Hindus, particularly the Kshetriya or the Thakur. In this way, the Tharus were "actively striving to achieve the social status" of being the Kshetriya or Thakur. Such dynamics in cultural attitudes were by the reasons of their "contact with the Hindus and other people of higher civilization" (23). Besides, Tharus in Uttar Pradesh of lowland Tarai were assuming the social reform by 'assimilation' process within the Kshetriya and Brahmin caste rather than preserving and promoting their homogenous based cultural tradition. Likewise, the scholarly work of Srivastava (1958), The Tharus: A Study in Cultural Dynamics, is an ethnography based study that mentions : "the basic needs of the Tharus were served by the 
institutions of their indigenous culture and how far their economic, social and religious patterns of life have been modified by their contacts of other religious groups, particularly Hindus" (x). Moreover, the Tharus have close attachment with the people of other castes and their cultures. Consequently, the process of adoption, acculturation and assimilation is advancing their dynamic process.

Moreover, Pyakurel's PhD dissertation (1982) gives details of the sociological problems with the inter-ethnic relations of assimilation, amalgamation and cultural pluralism among Chitwan Tharus. So his tendency of research portrays the sociological rather than anthropological perspective of Chitwaniya Tharus. Moreover, scholarly writing of Broker (1995) reveals the ethno-ecology of Chitwaniya Tharus. Dalzell (2015) explores the identity formation of Dangaura Tharus through folk musical practices and experiences. So her exploration infers the ethnomusical characteristics within the framework of ethnographical study. The researches of Acharya (2006), Tharu (2006), Tharu (2012, 2013) and Sarbahari (2015) reflect the literary aspects of Tharus in Nepal. Panjiar ( 2000), Gautam (1993), Singh (1988), Chaudhari (2013), Dahit (2016) spotlight the ethnohistorical facet of Tharus in Nepal. Similarly, Srivastavas (1958) highlights Rana Tharus of Nainital and, consequently, his inquiry aims to comprehend Ranas of Kanchanpur district and they also have contact with Indian Tharus.

\section{CONCLUSION}

The Tharus are scattered in several Tarai districts of Nepal, including eastern Jhapa to far-western Kanchanpur. Reviewing various published journal articles, $\mathrm{PhD}$ and MA dissertations and books, we can see the sufficient lacking on their studies. In other words, Tharus are minority in Nepali territory and their inclusion in academic arena portrays fertile area for further studies. Indeed, Krauskopff (1995) opines that western anthropologists were mostly paying attention to the Kathmandu valley as they were fascinated with the "rich heritage, the Himalayan Tibeto-Burman speakers and ethnically Tibetan groups" after when Nepal entered in the fifties (203). Thus, Tarai region and Tharus were not given priority for their study. Nepali anthropologist Bista’s book, People of Nepal (1967) became probably the first account in English for such study despite his writing on 
Tharus was only a too general explanation about the Tharus in Nepal. After Rajaure's MA dissertation in 1977, the concentration of the anthropological study in Tharus started. Then, McDonaugh and Krauskopff also put emphasis on in the step of Rajaure. At the same time, Guneratne (1994) gave emphasis to the anthropological appraisal of Chitwaniya Tharus.

The research in the community of Tharus is fertile area in Nepali context in the sense that their folk ways of life as well as cultural, social and historical factors seem hugely vary from one group to another. Moreover, most of the previous researches are focused on anthropology of Dangaura and more or less on Chitwaniya Tharus. The anthropological study of Dangaura and Chitwaniya Tharus is not fixed in the fluidities of the sociocultural facets as the existence of the ethnicity is not only primordial and unchanging model, but it has also the nature of contingent. Finally, we see the emerging of multidisciplinary discourses of various literary theories, including cultural materialism, spatiality, performance, ritual and folklore under the frame work of cultural studies in the academic arena of humanities and social sciences. Such interdisciplinary approach also helps to explore their rich folkloric, historical and cultural texts.

\section{ACKNOWLEDGEMENTS}

I am grateful to University Grants Commission (UGC) Nepal for providing the PhD fellowship and Research Support Grant 2074-75BS for this research.

\section{REFERENCES}

Acharya, G. (2014). Tharu jaatiko lokgeet tatha loksangeet. Kathmandu: Nepal Music Center.

Bista, D.B. (2008). Fatalism and development: Nepal's struggle for modernization. New Delhi: Orient Black Swan.

Bista, D.B. (2013). People of Nepal. Kathmandu: Ratna Pustak Bhandar.

CBS. (2012). National population and housing census 2011 (National Report). Kathmandu: Government of Nepal.

Chaudhary, M. (2013). Sthavirharuko prachin itihas ra sanskriti. Dang: Shanti Chaudhary. 
Dahit, G. (2016). Tharus'historical, social and cultural relations with Lord Buddha and Buddhism. PhD Thesis, Lumbini Buddhist University. Lumbini. Nepal

Dalzell, V. M. (2015). Freedom, margins and music: Musical discourses of Tharu ethnicity in Nepal. Unpublished PhD Thises. University of California, Riverside.

Gautam, T. (1987). Tharu jatiko itihas tatha sanskriti (Tharu Puran). Dang: Sushil Kumar Gautam.

Guneratne, A. (1969). The modernising matwalis: Caste, class and status among the Tharus of Chitwan. In Harold O Skar (ed.) Nepal: Tharu and Tarai neighbours. Kathmandu: Bibliotheca Himalayica. pp. 159-174.

Guneratne, A. (1998). Modernization, the state, and the construction of a Tharu identity in Nepal. The Journal of Asian Studies, 57(3): 749773.

Guneratne, A. (1998). The Tharus of Chitwan, ethnicity, class and the state in Nepal. Unpublished PhD Thesis (Anthropology), University of Chicago, USA.

Guneratne, A. (2002). Many tongues, one people: The making of Tharu identity in Nepal. London: Cornell University Press.

Guneratne, A. (2011). Tharu-State relations in Nepal and India. In Arjun Guneratne (ed.) The Tarai: History, society, environment, Kathmandu: Himal Books. pp. 27-53.

Haviland, W.A. (1999). Cultural anthropology. New York: Harcourt College Publishers.

Krauskopff, G. (1969). Corvees in Dang: Ethno-Historical Notes. In Harald O Skar (ed.) Nepal: Tharu and Tarai neighbours. Kathmandu: Bibliotheca Himalayica. pp 47-62.

Krauskopff, G. (1987). The birth of a Tharu village: concerning rituals of Tharu claustration. L'Ethnographie 83(100-101): 131-158. 
Krauskopff, G. (1990). The Tharu and the Hindu Kingdom of Dang (Nepal): Divine sovereignty and ethnic endogamy. L'Homme 116, 30(4): $30-40$.

Krauskopff, G. (1992). Divine receptions: On offerings and gods' embodiment among the Tharus of Nepal. Purusartha 15: 132-152.

Krauskopff, G. (1995). The anthropology of the tharu: An annoted bibliography. Kailash: A Journal of Himalayan Studies. 3(4): 85213.

Krauskopff, G. (2008). An Indigenous minority in a border area: Tharu Ethnic Associations, NGOs and the Nepalese State. In David N. Gellner (ed.). Resistance and the State: Nepalese experience. New Delhi: Social Science press. pp. 199-244.

Krauskopff, G. (2017). Interview. Voice of Tharus. https://tharuculture. blogspot.com/2017/01/tharu-identity-is-part-of-political.html.

McDonaugh, C. (1984). The Tharu of Dang: A dtudy of social organization, myth and ritual in west Nepal. Unpublished PhD Thesis, University of Oxford.

McDonaugh, C. (1989). The mythology of the Tharu: Aspects of cultural identity in Dang. Kailash: A Journal of Himalayan Studies, 25(34): 191-206.

McDonaugh, C. (1999). Aspects of social and cultural change in a Tharu village community in Dang, west Nepal, 1980-93. In Harald et al. (eds.) Nepal: Tharu and Terai Neighbors. Kathmandu: Bibliotheca Himalayica. pp. 223-35.

Panjiar, T. N. ( 2000). In my own words. In Gisele Krauskopff and Pamela Deuel Meyer (eds.) The Kings of Nepal \& the Tharu of the Tarai. Kirtipur: Centre for Nepal and Asian Studies. pp. 49-55.

Pyakurel, K. N. (1982). Ethnicity and rural development: A sociological study of four Tharu. Unpublished PhD Thesis, Department of Sociology, Michigan State University.

Rajaure, D. P. (1982). Tharus of Dang: Tharu religion. Kailash: A Journal of Himalayan Studies, 9(1): pp 61-96. 
Rajaure, D.P. (1977). Anthropological study of the tharus of DangDeokhuri. Unpublished MA Thesis, CNAS, Tribhuvan University, Kathmandu.

Roy, I. B. (2003). Anthropology: The study of man. New Delhi: S Chand \& Company Ltd.

Sarbahari, K. (2016). Tharu sahityako itihas. Kathmandu: Nepal Academy.

Singh, R. P. (1988). The real story of the Tharus. Kathmandu: Tharu Sanskriti.

Srivastava, S.K. (1958). The Tharus: A study in cultural dynamics. Ahmadabad: New Order Book Co.

Srivastava, S.K. (1969). Cultural dynamics among the rana Tharus: The past in the present. In Harald O Skar (ed.) Nepal: Tharu and Tarai neighbours. Kathmandu: Bibliotheca Himalayica. pp 9-26.

Tharu, A. (2006). Tharu loksāhityamā itihās, kala ra darshan. Tulsipur, Dang: Change Agent's Forum-Nepal.

Tharu, P. S. (2012). Tharu loksanskriti ra chaadbaad. Kathmandu: Nepal Academy.

Tharu, P. S. (2013). Tharu lok sahitya: Ek adhyan. Lalitpur: Adibasi Janajati Utthan Rastriya Pratishthan. 